Article

\title{
Social Sustainability of Provinces in China: A Data Envelopment Analysis (DEA) Window Analysis under the Concepts of Natural and Managerial Disposability
}

\author{
Toshiyuki Sueyoshi ${ }^{1}$, Yan Yuan ${ }^{1}$, Aijun $\mathrm{Li}^{2, *}$ and Daoping Wang ${ }^{2}$ \\ 1 New Mexico Institute of Mining \& Technology, Department of Management, 801 Leroy Place, Socorro, \\ NM 87801, USA; toshiyuki.sueyoshi@nmt.edu (T.S.); margaretmity@gmail.com (Y.Y.) \\ 2 The Center for Economic Research, Shandong School of Development, Shandong University, Jinan 250100, \\ China; dpwang.edu@gmail.com \\ * Correspondence: liaijun@sdu.edu.cn; Tel.: + 86-531-8836-3958
}

Received: 5 October 2017; Accepted: 7 November 2017; Published: 18 November 2017

\begin{abstract}
Natural and managerial disposability are two important strategic concepts, whose priorities are economic prosperity and environmental protection, respectively. This study defines social sustainability as the simultaneous achievement of economic prosperity and environmental protection, and then assesses the degree of social sustainability across provinces in China. In addition, this study combines the concepts of natural and managerial disposability with Data Envelopment Analysis window analysis. The method allows for frontier shifts among different time periods and thus can provide more stable and reliable results. This method is applied to assess the energy and environmental performances across the provinces of China during 2003-2014, and provides detailed information about provincial variations, which are valuable and important to policy makers (especially for those in local governments). This study identifies three important findings. First, there were no significant improvements in China's environmental performance during the analysis periods, since, historically, the governments have not paid enough attention to environmental protection. Second, there are increasing trends in the provincial gaps regarding the environmental performance. In this regard, the central government should help the poor provinces to protect the environment. Third, there are significant differences between the results obtained under natural disposability and those obtained under managerial disposability, since they have different priorities regarding the operational and the environmental performances. Thus, significant contributions can be made by eco-technology progress combined with managerial performance improvements by business leaders and policy makers. This can be a new policy direction for the Chinese government.
\end{abstract}

Keywords: data envelopment analysis; DEA window analysis; social sustainability; eco-technology progress; natural disposability; managerial disposability

\section{Introduction}

The Chinese government is under a growing environmental pressure as a result of its rapid economic development. China faces serious environmental issues, because of the large annual and cumulative historical emissions or discharges (hereafter, emissions) of various pollutants. In 2014, China's $\mathrm{CO}_{2}$ emissions (The data of Hong Kong are not included.) reached 9.15 billion tons, accounting for $28.21 \%$ of the world's total [1]. According to [2], the emissions of various pollutants, such as $\mathrm{SO}_{2}$ (19.74 million tons), chemical oxygen demand (COD, 22.95 million tons), and ammonia nitrogen (2.39 million tons) remained large in 2014. Even worse, there was an upward time trend for some industrial pollutants, such as soot and dust (17.41 million tons in 2014), and waste water 
(71.6 billion tons in 2014). Therefore, it is urgent for the Chinese government to adopt well-designed environmental policies.

When developing well-designed environmental policy regimes, it is a prerequisite to access the available detailed information about provincial variations. In China, provincial gaps can be quantified in many economic and environmental indicators. This study takes annual growth rates of some industrial pollutants from 2003 to 2014 as an example, analyzing data obtained from [2]). As for waste water, the average annual growth rates ranged from $0.96 \%$ to $8.97 \%$, indicating that all provinces experienced a growth in emissions, with quantitative differences across provinces. Also, similar results can be found in terms of ammonia nitrogen, with average annual growth rates ranging from $3.19 \%$ to $22.16 \%$. However, things are different for some other industrial pollutants. Regarding $\mathrm{SO}_{2}$, there were 15 provinces with negative growth rates and 15 provinces with positive growth rates. Concerning soot (dust), 11 provinces showed a negative growth and 19 provinces experienced a positive growth. Thus, there are large differences both qualitatively and quantitatively across provinces and across pollutants. In this respect, this study provides detailed information by measuring the unified efficiency at provincial levels, which is a valuable and important piece of data for policy makers, especially for those in local governments.

Furthermore, the trade-off between environmental protection and economic prosperity has to be considered [3]. The traditional data envelopment analysis (DEA) is not capable of incorporating economic prosperity and pollution protection in a unified framework. To solve this problem, Sueyoshi and his associates (e.g., [4,5]) proposed two strategic concepts, namely, natural and managerial disposability. By comparison, these two disposability concepts have different priorities. Under natural disposability, the first priority is the operational performance and the second priority is the environmental performance. On the contrary, under managerial disposability, the first priority is the environmental performance and the second priority is the operational performance. Under these two new concepts, the economic prosperity and the environmental protection can be assessed at the same time. Here, this study defines social sustainability as the simultaneous achievement of economic prosperity and environmental protection and then assesses the social sustainability of the provinces in China.

Meanwhile, the conventional DEA studies assume that the efficiency frontier does not retreat over time, implying that frontier shifts are impossible across time periods. To overcome this problem, DEA window analysis was proposed by [6] and developed by the following, related studies. DEA window analysis combines observations for a few adjacent years into a window and then creates a new efficiency frontier. This method allows for frontier shifts between time periods.

Based on the previous studies, our study combines the concepts of natural and managerial disposability with DEA window analysis. In this way, the method can assess environmental protection and economic prosperity simultaneously. Further, this method allows for frontier shifts between different time periods. One important finding is that there should be significant contributions from eco-technology progress and managerial performance improvements by business leaders and policy makers [7]. This can be a new direction of climate policies [8]. This type of analysis has never been performed in the previous studies of China's environmental assessment. The rest of this study is structured as follows: Section 2 describes a literature review, Section 3 introduces China's regional and environmental policies, Section 4 formulates the DEA models under natural and managerial disposability and introduces the methodology of DEA window analysis, Section 5 applies the proposed approach to an illustrative example regarding China's regional assessment, and Section 6 concludes the study.

\section{Literature Review}

Three lines of research are highly related to the work in this paper. The first line of research is related to DEA window analysis. DEA window analysis was first proposed by [6] under the supervision of Professor W.W. Cooper. Ref. $[9,10]$ developed the Malmquist productivity index, 
by combining window analysis and the Malmquist index. Ref. [11] summarized the strengths and drawbacks of DEA window analysis. Ref. [12] developed a computational framework to consider undesirable outputs within DEA window analysis. Methodologically, DEA window analysis creates a new efficiency frontier by combining observations for a few adjacent years into a window, and thus allows for frontier shifts between time periods. One important feature is that DEA window analysis eliminates the assumption that an efficiency frontier does not retreat. There are also some recent applications, such as those of $[13,14]$.

The second line of research regards the DEA studies about disposability concepts, where disposability refers to the elimination of inefficiency. Two groups of concepts of disposability have been adopted in the existing studies, i.e., strong and weak disposability versus natural and managerial disposability [15-18]. Following the concepts of natural and managerial disposability, there are two related concepts: desirable congestion and undesirable congestion. The first group of concepts (weak and strong disposability) was initially proposed by [19] and is dominant in the existing DEA studies (see, for example, [20,21]). Meanwhile, the second group of disposability concepts was created and adopted by some studies in recent years, such as the studies of [4,5,22-31].

It is noteworthy that the weak disposability is equivalent to the natural disposability with equality (thus, no slack) on undesirable outputs, implying that the weak disposability can become a special case of the natural disposability. Furthermore, the managerial disposability allows for a possible occurrence of desirable congestion, whereas both the weak and the strong disposability do not. In this respect, the concepts of natural and managerial disposability should attract sufficient attention in environmental studies, especially when there is an occurrence of desirable congestion or eco-technology innovation. The underlying policy implication of managerial disposability is that environmental issues can be overcome by the combined efforts of eco-technology advancements in natural science along with managerial performance improvements by business leaders and policy makers (see a detailed discussion in $[28,29])$.

The third line of research regards the DEA studies on China's regional assessment. Up to now, great research interest has been concentrated on China's regional assessment, since China faces serious environmental issues (Some previous studies, such as those of $[18,32,33]$ provided a literature survey regarding the applications of DEA models in energy and environment. This study focuses on the literature about China's regional assessment). In the meantime, DEA has gained a methodological reputation for performance assessment. Table 1 summarizes 20 papers about the applications of DEA to China's regional assessment from 2010 to 2017. The table provides us with the following two interesting concerns: first, most of the 20 papers assessed both the energy efficiency ( 20 papers) and the environmental efficiency (18 papers); second, there were 12 papers about $\mathrm{CO}_{2}, 10$ papers about other industrial pollutants, and five papers combining $\mathrm{CO}_{2}$ with industrial pollutants. Therefore, environmental issues and sustainability have become an important research focus of the DEA studies about China's regional assessment.

Position of this study: compared to the most recent papers about the conceptual shift to natural and managerial disposability, this study applies window analysis using the radial model under two disposability concepts. [28] proposed the intermediate model to analyze Chinese sustainable development. [29] further compared three different and most commonly used methods, which are the radial, non-radial, and intermediate models of analysis. Even though [29] implemented the radial model in Chinese municipalities and provinces, their paper evaluated the potential for Chinese development using the Malmquist index and pooling together the data from all years. Our study utilizes the radial model to evaluate the efficiency by using moving averages. In other words, the analysis outcome focuses on the recent years by different windows. Therefore, the advantage of this study is that the policy implication that we found is more accurate and credible. 
Table 1. Existing DEA studies on China's regional assessment.

\begin{tabular}{|c|c|c|c|}
\hline Authors & Desirable Outputs & Undesirable Outputs & Inputs \\
\hline$[34]$ & GDP & $\mathrm{CO}_{2}, \mathrm{SO}_{2}$ & $\begin{array}{l}\text { Labor, capital, coal, crude oil, } \\
\text { natural gas }\end{array}$ \\
\hline [35] & GDP & & Labor, capital, energy \\
\hline [36] & Industrial added value & $\mathrm{CO}_{2}$ & Labor, capital, energy \\
\hline [37] & GDP & & Labor, capital, energy \\
\hline [38] & GDP & $\begin{array}{l}\text { Waste water, waste gas } \\
\text { and solid waste }\end{array}$ & Labor, capital, energy \\
\hline [39] & Industrial added value & $\mathrm{CO}_{2}, \mathrm{SO}_{2}$ & Labor, capital, energy \\
\hline [40] & Industrial added value & $\mathrm{NO}_{2}$ & Capital, electricity \\
\hline [41] & GDP & $\mathrm{CO}_{2}$ & Labor, capital, energy \\
\hline$[42]$ & GDP & $\mathrm{CO}_{2}, \mathrm{SO}_{2}$ & Labor, capital, coal, electricity \\
\hline [20] & GDP & $\mathrm{CO}_{2}$ & Labor, capital, energy \\
\hline [43] & Industrial added value & Waste water, solid waste & Labor, capital, coal \\
\hline$[44]$ & Industrial added value & $\mathrm{CO}_{2}$ & Labor, capital, energy \\
\hline [45] & GDP & $\mathrm{CO}_{2}$ & Labor, capital, energy \\
\hline [46] & GDP & Solid waste & Labor, capital, coal \\
\hline [47] & GDP & $\mathrm{SO}_{2}$, solid waste & Labor, capital, energy \\
\hline [48] & GDP & $\begin{array}{l}\mathrm{CO}_{2}, \mathrm{SO}_{2} \text {, solid waste, } \\
\text { industrial dust }\end{array}$ & Labor, capital, energy \\
\hline [49] & GDP & $\mathrm{CO}_{2}$ & Labor, capital, energy \\
\hline [21] & GDP & $\mathrm{CO}_{2}$ & Labor, capital, energy \\
\hline
\end{tabular}

\section{China's Current Environmental Policies}

It is necessary for this study to briefly introduce China's political organs and environmental policies, since they are quite different from those in other developed countries (such as the United States, the European countries, and Japan). Without other clear statements, the following information was obtained through the websites of the State Council of China (SC) or of the Ministry of Environmental Protection of China (MEP) [50,51].

Concerning the environmental protection, the major political organs are introduced below. Among all political organs, the National People's Congress (NPC) is the highest organ in terms of state power. It has the right to enact the law and to create and supervise all political organs (such as the administrative and judicial organs). Laws are final decisions of utmost importance for the NPC (or its standing committee). During the past few years, a series of laws concerning the environmental protection has been passed or amended. These laws are mainly concerned with air pollution, water pollution, solid waste, energy consumption, cleaner production, environmental protection, and environmental impact.

The central government and local governments are the executive organ. The SC is the central government and has the right to enact administrative measures, administrative rules, and regulations. As the executive branch of the central government, the MEP is responsible for implementing environmental policies and enforcing environmental laws and regulations, with the task of protecting air, water, and land from pollution and contamination. Meanwhile, there are five levels of governments. China is a centralized state, and environmental policies are decided by the central government. Administratively, China is divided into provinces (or province-equivalents), cities (or city-equivalents), counties (or county-equivalents), and towns (or town-equivalents). Local governments are under 
the leadership of the central government and upper-level governments. Consequently, there exists a relatively rigid hierarchy among the various levels of governments.

The SC is responsible for developing and implementing environmental policies and administrative measures to curb the environmental pollution. To obtain accurate information, China sets up a large number of monitoring stations, with the purpose of tracking and measuring the degree of environmental pollution. According to the [2], there are 2497 atmospheric monitoring stations, 979 acid rain monitoring stations, 9568 surface water quality monitoring sections, and 59,123 monitoring stations in major enterprises. These monitoring stations can provide accurate information on the changes of environmental pollutions across cities (or city-equivalents) in China.

Environmental plans and programs set targets of environmental protection. In China, the Five-Year Plan (or Guideline) sets the targets for environmental protection. The central government announced the new reduction targets during the Thirteenth Five-Year Plan period (2016-2020), including the reduction of COD $(10 \%)$, ammonia nitrogen $(10 \%), \mathrm{SO}_{2}(15 \%)$, and nitrogen oxides $(15 \%)$. Meanwhile, the Chinese government announced the targets of energy saving and carbon emission reductions, which include reducing the peaking $\mathrm{CO}_{2}$ emissions by 2030, reducing carbon intensity by $60-65 \%$ relative to 2005 levels, and increasing the use of non-fossil fuel to $20 \%$ of the total primary energy consumption.

To fulfill the above targets, the Chinese government has implemented an environmental protection tax and pollution rights trading systems. Meanwhile, the government proposes the principle that the polluter pays, and a third party supervises and abates. According to this principle, polluters should pay for pollution, wherein the payment is used to promote environmental industries. In turn, environmental industries should take the responsibility of pollution abatement. To this end, the Environmental Protection Tax Law will come into force in 2018, and, at that point, the polluters should pay the environmental protection tax. Furthermore, the Implementation Scheme for Certificates of Pollution Rights was issued in 2016, indicating that the Chinese government would establish national markets for pollution rights trading by 2020 . The pollution rights trading systems could promote environmental industries and reduce the environmental pollution effectively.

\section{Methodology}

All nomenclatures used in methodology are summarized as follows: $j$, the subscript of undesirable output $(j=1, \ldots, J) ; m$, the subscript of input $(m=1, \ldots, M) ; n$, the subscript of decision-making unit (DMU) $(n=1, \ldots, N) ; s$, the subscript of desirable output $(s=1, \ldots, S) ; x$ : inputs; $y$ : desirable outputs; $b$ : undesirable outputs; $d_{m}^{x}$ : slack variable of inputs; $d_{s}^{y}$ : slack variable of desirable outputs; $d_{j}^{b}$ : slack variable of undesirable outputs; $\lambda$ : intensity (or structural) variables; $R_{m}^{x}$ : a data range related to inputs; $R_{s}^{y}$ : a data range related to desirable outputs; $R_{j}^{b}$ : a data range related to undesirable outputs; $\varepsilon_{a}$ : a very small number to reduce the influence of slacks on unified efficiency; RTS: returns to scale; UEM: unified efficiency under managerial disposability; UEN: unified efficiency under natural disposability; URS: Unrestricted.

\subsection{The Production Technologies and the Concepts of Disposability}

The production technology transforms factors of inputs $\left(x \in \mathcal{R}_{+}^{M}\right)$ into desirable outputs $\left(y \in \mathcal{R}_{+}^{S}\right)$ and undesirable outputs $\left(b \in \mathcal{R}_{+}^{J}\right)$. In this case, the production technologies can be written as follows:

$$
T=\{(x, y, b): x \text { can produce } y \text { and } b\} \in \mathcal{R}_{+}^{M}
$$

Then, the production possibility sets under natural and managerial disposability and constant returns to scale can be expressed as follows:

$$
P_{c}^{N}(X)=\left\{\begin{array}{c}
(Y, B): Y \leq \sum_{n=1}^{N} Y_{n} \lambda_{n}, B \geq \sum_{n=1}^{N} B_{n} \lambda_{n}, X \geq \sum_{n=1}^{N} X_{n} \lambda_{n}, \\
\lambda_{n} \geq 0(n=1, \ldots, N)
\end{array}\right\}
$$




$$
P_{v}^{M}(X)=\left\{\begin{array}{c}
(Y, B): Y \leq \sum_{n=1}^{N} Y_{n} \lambda_{n}, B \geq \sum_{n=1}^{N} B_{n} \lambda_{n}, X \leq \sum_{n=1}^{N} X_{n} \lambda_{n}, \\
\lambda_{n} \geq 0(n=1, \ldots, N)
\end{array}\right\}
$$

From the above equations, it can be found that there is a clear difference in the production possibility sets between natural and managerial disposability, since they have different inequality signs related to the production inputs $\left(X \geq \sum_{j=1}^{n} X_{j} \lambda_{j}\right.$ vs. $\left.X \leq \sum_{j=1}^{n} X_{j} \lambda_{j}\right)$. That is, under natural disposability, an efficiency frontier for the production inputs should locate above or on all observations. In contrast, under managerial disposability, an efficiency frontier for the production inputs should locate below or on all observations. The underlying policy implication is that inefficient decision-making units can improve the efficiency by decreasing the production inputs under natural disposability and by increasing the production inputs under managerial disposability.

The production possibility sets under natural and managerial disposability share the same equations, that are: $Y \leq \sum_{j=1}^{n} Y_{j} \lambda_{j} \& B \geq \sum_{j=1}^{n} B_{j} \lambda_{j}$. Therefore, the potential implications are that inefficient decision-making units can improve the efficiency by increasing the desirable outputs, by reducing the undesirable outputs, or both.

Here, this study defines social sustainability as the simultaneous achievement of economic prosperity and environmental protection, following $[27,28]$. The main reasons are as follows: increasing the desirable outputs means producing improvements and thus reflects the degree of economic prosperity; meanwhile, reducing the undesirable outputs implies the reduction of pollutants and hence corresponds to the level of environmental protection. In this way, social sustainability can be reflected in the changes of the production variables.

\subsection{Unified Efficiency and the Disposability Concepts}

This study utilizes a radial DEA model to measure the level of unified efficiency, after referring to $[15,23]$. To achieve this purpose, the data range needs to be restructured as follows:

$$
\begin{aligned}
& R_{m}^{x}=(m+s+j)^{-1}\left(\begin{array}{c}
\max \left\{\left|\bar{x}_{\text {mnt }}\right| \mid n=1, \ldots N \& t=1, \ldots, T\right\} \\
-\min \left\{\left|\bar{x}_{m n t}\right| \mid n=1, \ldots N \& t=1, \ldots, T\right\}
\end{array}\right)^{-1} \\
& R_{s}^{y}=(m+s+j)^{-1}\left(\begin{array}{c}
\max \left\{\left|\bar{y}_{\text {snt }}\right| \mid n=1, \ldots N \& t=1, \ldots, T\right\} \\
-\min \left\{\left|\bar{y}_{\text {snt }}\right| n=1, \ldots N \& t=1, \ldots, T\right\}
\end{array}\right) \\
& R_{j}^{b}=(m+s+j)^{-1}\left(\begin{array}{c}
\max \left\{\left|\bar{b}_{j n t}\right| \mid n=1, \ldots N \& t=1, \ldots, T\right\} \\
-\min \left\{\left|\bar{b}_{j n t}\right| \mid n=1, \ldots N \& t=1, \ldots, T\right\}
\end{array}\right)
\end{aligned}
$$

Then, this study solves the following DEA model:

$$
\begin{array}{ll}
\text { Maximize } & \xi+\varepsilon_{a}\left(\sum_{m=1}^{M} R_{m}^{x} d_{m}^{x-}+\sum_{s=1}^{S} R_{s}^{y} d_{s}^{y}+\sum_{j=1}^{J} R_{j}^{b} d_{j}^{b}\right) \\
\text { s.t. } & \sum_{n=1}^{N} x_{m n} \lambda_{n}+d_{m}^{x-}=x_{m k}(m=1, \ldots, M), \\
& \sum_{n=1}^{N} y_{s n} \lambda_{n}-d_{s}^{y}-\xi y_{s k}=y_{s k}(s=1, \ldots, S), \\
& \sum_{n=1}^{N} b_{j n} \lambda_{n}+d_{j}^{b}+\xi b_{j k}=b_{j k}(j=1, \ldots, J), \\
& \lambda_{n} \geq 0(n=1, \ldots, N), \xi: U R S, d_{m}^{x-} \geq 0(m=1, \ldots, M), \\
& d_{s}^{y} \geq 0, d_{j}^{b} \geq 0(s=1, \ldots, S) .
\end{array}
$$

Based on the results of the above DEA, the unified efficiency values under natural disposability can be measured as follows: 


$$
U E N=1-\left[\xi^{*}+\varepsilon_{a}\left(\sum_{m=1}^{M} R_{m}^{x} d_{m}^{x-*}+\sum_{s=1}^{S} R_{s}^{y} d_{s}^{y *}+\sum_{j=1}^{J} R_{j}^{b} d_{j}^{b *}\right)\right]
$$

Unified efficiency scores are obtained when the desirable outputs are maximized and the undesirable outputs are minimized. Thus, their values can reflect the degree of social sustainability. The same is true in the case of managerial disposability.

Likewise, unified efficiency values under managerial disposability can be obtained by solving the following model:

$$
\begin{array}{ll}
\text { Maximize } & \xi+\varepsilon_{a}\left(\sum_{m=1}^{M} R_{m}^{x} d_{m}^{x-}+\sum_{s=1}^{S} R_{s}^{y} d_{s}^{y}+\sum_{j=1}^{J} R_{j}^{b} d_{j}^{b}\right) \\
\text { s.t. } & \sum_{n=1}^{N} x_{m n} \lambda_{n}-d_{m}^{x-}=x_{m k}(m=1, \ldots, M), \\
& \sum_{n=1}^{N} y_{s n} \lambda_{n}-d_{s}^{y}-\xi y_{s k}=y_{s k}(s=1, \ldots, S), \\
& \sum_{n=1}^{N} b_{j n} \lambda_{n}+d_{j}^{b}+\xi b_{j k}=b_{j k}(j=1, \ldots, J), \\
& \lambda_{n} \geq 0(n=1, \ldots, N), \xi: \text { URS }, d_{m}^{x-} \geq 0(m=1, \ldots, M), \\
& d_{s}^{y} \geq 0, d_{j}^{b} \geq 0(s=1, \ldots, S) .
\end{array}
$$

Technically, the unified efficiency values under managerial disposability are measured by the following formula:

$$
\begin{aligned}
U E M & =1-\left[\xi^{*}+\varepsilon_{a}\left(\sum_{m=1}^{M} R_{m}^{x} d_{m}^{x-*}+\sum_{s=1}^{S} R_{s}^{y} d_{s}^{y *}+\sum_{j=1}^{J} R_{j}^{b} d_{j}^{b *}\right)\right] \\
& =1-\left[\sum_{m=1}^{M} v_{m}^{*} x_{m k}-\sum_{s=1}^{S} u_{s}^{*} y_{s k}+\sum_{j=1}^{J} w_{j}^{*} b_{j k}+\sigma^{*}\right]
\end{aligned}
$$

\subsection{DEA Window Analysis}

Following [26], this study combines three adjacent years into a window and thus creates a new frontier. In this way, DEA window analysis allows for frontier shifts among different time periods, where frontiers can retreat over time.

In a time horizon, the input and output variables can be specified as follows:

$$
\begin{array}{cc}
\bar{x}_{m n}=x_{m n}+\alpha_{m} & (m=1, \ldots, M) \\
\bar{y}_{s n}=y_{s n}+\beta_{s} & (s=1, \ldots, S) \\
\bar{b}_{j n}=b_{j n}+\delta_{j} & (j=1, \ldots, J)
\end{array}
$$

The windows are created as follows:

$$
P_{P B(t)}=P_{t-2 \cup t-1 \cup t}, \text { for } t=3, \ldots, T
$$

Then, the DEA model is specified in a time horizon, and this study can obtain the results based on the DEA window analysis.

\section{Empirical Results}

\subsection{The Data}

In this study, there are 30 provinces or province-equivalents (called provinces for short), wherein every province is considered as a decision-making unit. The data of Tibet, Hong Kong, Taiwan, and 
Macau are excluded, because of limited data availability. The data regard a time period from 2003 to 2014 .

This study considers three production inputs, one desirable output, and six undesirable outputs. The three production inputs are measured by: (a) capital $\left(10^{8} \mathrm{RMB}\right),(\mathrm{b})$ labor (persons), and (c) energy $\left(10^{4}\right.$ tce). The desirable outputs are measured by the gross regional product (GRP, $\left.10^{8} \mathrm{RMB}\right)$. The undesirable outputs are measured by six items: (a) the annual amount of $\mathrm{CO}_{2}\left(10^{4}\right.$ tons), (b) the annual amount of $\mathrm{SO}_{2}\left(10^{4}\right.$ tons), (c) the annual amount of soot and dust $\left(10^{4}\right.$ tons), (d) the annual amount of waste water ( $10^{4}$ tons), (e) the annual amount of COD $\left(10^{4}\right.$ tons), and (f) the annual amount of ammonia nitrogen ( $10^{4}$ tons).

In particular, the capital input is calculated according to the perpetual inventory (stock) system, after referring to the results and method in [52]. The base year is 2003. During the calculation, the gross fixed capital formation and the price indices of investment in fixed assets are taken from [53,54]. The labor input is calculated according to the employment and earnings in urban collective-owned units, as in [55]. The energy input is measured as total energy consumption across provinces, as in [56]. In terms of desirable output, GRP is calculated based on indices of GRP across provinces with 2003 as the base year. The data source is [53]. As for the undesirable output, except $\mathrm{CO}_{2}$, the data come from the [2]. Meanwhile, the carbon dioxide emissions are assumed to be the product of the energy consumption and the emission factor of energy, which is calculated based on the method in [57]. Technically, carbon dioxide emissions are calculated as follows:

$$
E C=\sum_{i} E C_{i}=\sum_{i}\left(E_{i} \times C F_{i} \times C C_{i} \times C O F_{i} \times 3.67\right)
$$

Wherein:

Subscript $i$ represents different kinds of energy, EC represents carbon dioxide emissions, $E$ represents energy consumption, $C F$ represents the calorific value of energy, $C C$ represents the carbon content of energy, and COF represents the oxidation factor of energy.

In Equation (11), the emission factor of energy is the product of the calorific value, the carbon content, and the oxidation factor of energy. The data sources are the $[56,58,59]$.

Table 2 summarizes the descriptive statistics of the input and output variables used in this study, where Ave., S.D., Min. and Max. stand for mean, standard deviation, minimum, and maximum, respectively. It shows that (1) among the production inputs, there are large annual rises in the mean of capital $(9.47 \%)$, and considerable rises in the energy input (3.54\%) and the labor input $(2.94 \%)$; (2) as for the desirable outputs, there are significant increases in the mean of GRP $(6.59 \%)$; (3) regarding the undesirable outputs, there are large increases in the annual rises in the mean of ammonia nitrogen $(6.45 \%)$ and $\mathrm{COD}(5.45 \%)$, a considerable growth in $\mathrm{CO}_{2}(3.74)$, slight changes in waste water $(1.98 \%)$ and soot and dust $(1.51 \%)$, and slight decreases in $\mathrm{SO}_{2}(-0.98 \%)$. Therefore, the above data indicate that different variables change disproportionally across time.

Table 2. Descriptive statistics of production variables from 2003 to 2014.

\begin{tabular}{|c|c|c|c|c|c|c|c|c|c|c|}
\hline & & Inputs & & Desirable Outputs & & & Undesir & le Outpu & & \\
\hline & Capital & Labor & Energy & GRP & $\mathrm{CO}_{2}$ & $\mathrm{SO}_{2}$ & $\begin{array}{l}\text { Smoke } \\
\text { and dust }\end{array}$ & $\begin{array}{l}\text { Waste } \\
\text { water }\end{array}$ & $\begin{array}{l}\text { chemical } \\
\text { oxygen } \\
\text { demand }\end{array}$ & $\begin{array}{l}\text { Ammonia } \\
\text { Nitrogen }\end{array}$ \\
\hline & $10^{8} \mathrm{RMB}$ & persons & $10^{4}$ tce & $10^{8} \mathrm{RMB}$ & \multicolumn{6}{|c|}{$10^{4}$ tons } \\
\hline Ave. & 22,500 & $4,466,555$ & 11,430 & 9706 & 23,438 & 75.25 & 53.70 & 196,290 & 56.33 & 5.70 \\
\hline S.D. & 20,108 & $2,901,815$ & 7633 & 8877 & 16,309 & 44.51 & 37.96 & 156,976 & 39.55 & 4.13 \\
\hline
\end{tabular}




\subsection{Unified Efficiency under Natural and Managerial Disposability}

This subsection discusses the unified efficiency of 30 provinces in China, taking into consideration the natural disposability and the managerial disposability.

Table 3 lists the unified efficiency scores under natural disposability and constant returns to scale, and Table 4 presents the unified efficiency scores under managerial disposability and constant returns to scale. Figure 1 depicts the average unified efficiency of China. Values equal to 1 imply that the province is on the production frontier or technically efficient in the associate year. Values below 1 imply that the province is below the frontier or technically inefficient.

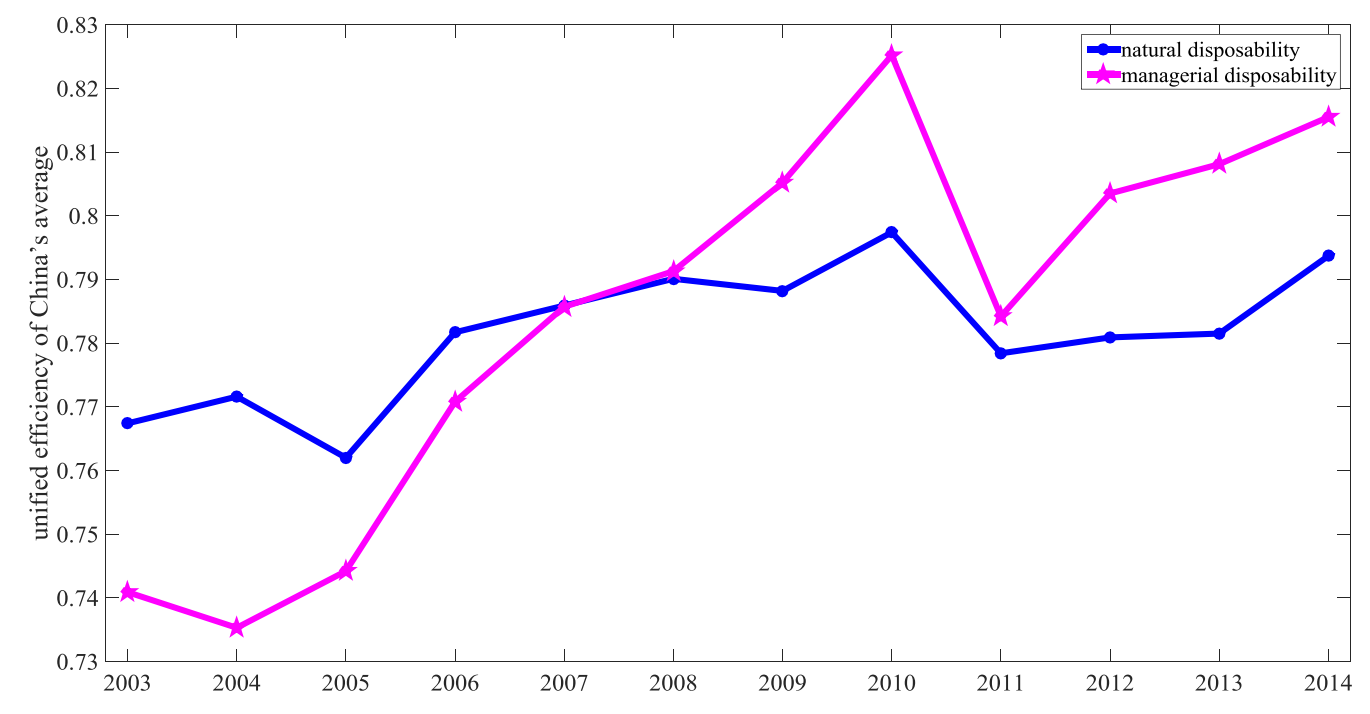

Figure 1. China's average unified efficiency without window analysis.

Figure 2 shows that there is a slightly increasing time trend for China's average unified efficiency score under natural or managerial disposability. These results indicate that there are small improvements of the environmental performance in the provinces of China.

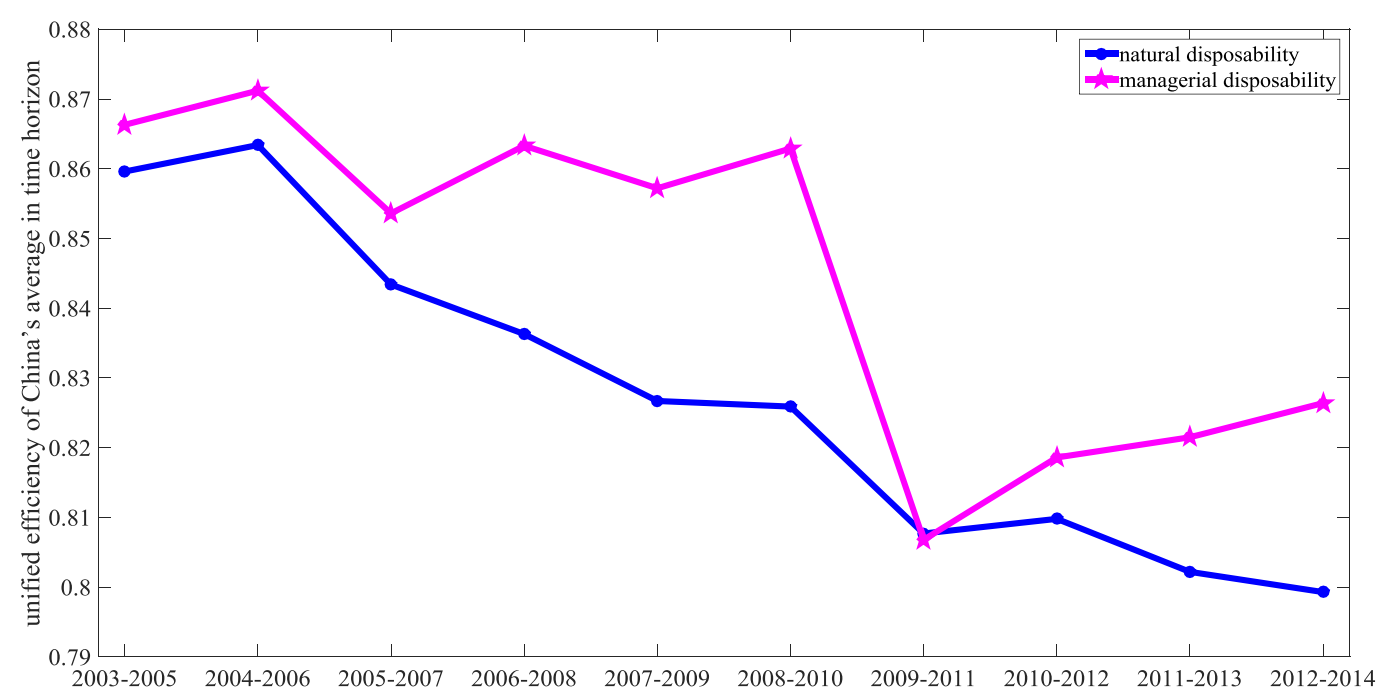

Figure 2. China's average unified efficiency with window analysis.

Tables 3 and 4 provide us with the following three interesting concerns. First, some provinces operate on the frontier, i.e., three provinces in 2014 under natural disposability, and one province in 2003 
and four provinces in 2014 under managerial disposability. By contrast, most provinces are not technical efficient and, thus, they can improve their technical efficiency by "catching up". In addition, it can be seen that there are different potentials across provinces to improve their environmental performance.

Second, all provinces can be classified into two different groups concerning the change rates of unified efficiency. The first group of provinces shows upward time trends, and most provinces belong to this group. According to the average growth rates of unified efficiency, there are about 18 provinces in natural disposability and 26 provinces in managerial disposability, indicating that the environmental performance increases over time in these provinces. By contrast, the second group of provinces shows downward time trends in terms of unified efficiency scores. There are 12 provinces in natural disposability and four provinces in managerial disposability, meaning that insufficient attention has been paid to environmental issues in these provinces. The above results imply that there are considerable variations across provinces.

\subsection{Window Analysis and Unified Efficiency}

This subsection discusses the results of window analysis, which considers the time horizon and captures frontier shifts between different time periods. The purpose is to examine how much the unified efficiency scores change when three adjacent years are combined into one window.

Figure 2 illustrates the average unified efficiency of China with window analysis. The scores tend to decrease with time, with window analysis under natural or managerial disposability. In contrast to Figures 1 and 2, one can make quite different conclusions, regardless of the way the results are calculated, i.e., by DEA without or with window analysis. These results are not surprising, since the production frontiers are based on all observations in Figure 1, and on limited observations in Figure 2. The underlying implication is that there are technical changes across time. In terms of comparison across time, DEA window analysis can provide more steady and reliable results.

Quite importantly, it is worthwhile to note that there are significant increases in China's average unified efficiency scores under managerial disposability (in Figure 1). Furthermore, the unified efficiency scores under managerial disposability surpass those under natural disposability in almost all analysis periods (in Figure 2). Therefore, improving managerial performance can make significant contributions to the environmental protection.

Table 5 presents the unified efficiency scores under natural disposability and constant returns to scale in the time horizon, and Table 6 lists the unified efficiency scores under managerial disposability. The following two interesting concerns are found. First, some provinces operate on the frontier, i.e., three provinces in the window of 2012-2014 under natural disposability and six provinces in the window of 2012-2014 under managerial disposability. In addition, other provinces are not technical efficient. Second, regarding the average change rates of unified efficiency, there are eight provinces under natural disposability and 16 provinces under managerial disposability with average growth rates of unified efficiency exceeding the unity. Thus, these provinces show downward time trends. By comparison, other provinces show upward time trends. 
Table 3. Unified efficiency scores under natural disposability.

\begin{tabular}{|c|c|c|c|c|c|c|c|c|c|c|c|c|}
\hline Province & 2003 & 2004 & 2005 & 2006 & 2007 & 2008 & 2009 & 2010 & 2011 & 2012 & 2013 & 2014 \\
\hline BJ & 0.8059 & 0.8340 & 0.8807 & 0.9064 & 0.9571 & 0.9809 & 0.9857 & 1.0000 & 0.9842 & 0.9855 & 0.9947 & 1.0000 \\
\hline TJ & 0.8889 & 0.9160 & 0.8947 & 0.9171 & 0.9452 & 0.9645 & 1.0000 & 1.0000 & 1.0000 & 0.9799 & 1.0000 & 1.0000 \\
\hline HEB & 0.8437 & 0.8380 & 0.8516 & 0.8609 & 0.8620 & 0.8314 & 0.8253 & 0.8521 & 0.8447 & 0.8237 & 0.8278 & 0.8421 \\
\hline SX & 0.7857 & 0.8163 & 0.8190 & 0.8285 & 0.8111 & 0.7824 & 0.7162 & 0.7062 & 0.7302 & 0.6974 & 0.6946 & 0.6680 \\
\hline IM & 0.9628 & 0.9464 & 0.9181 & 0.9014 & 0.9031 & 0.8837 & 0.8822 & 0.8538 & 0.8656 & 0.8929 & 0.8741 & 0.9448 \\
\hline $\mathrm{LN}$ & 0.8212 & 0.8356 & 0.7909 & 0.8038 & 0.7972 & 0.8028 & 0.7979 & 0.8525 & 0.8421 & 0.8540 & 0.8527 & 0.8387 \\
\hline JL & 0.8347 & 0.8364 & 0.7962 & 0.7901 & 0.7233 & 0.6802 & 0.6836 & 0.6960 & 0.7214 & 0.7490 & 0.7529 & 0.7537 \\
\hline HLJ & 0.8540 & 0.9028 & 0.9353 & 0.9676 & 0.9830 & 0.9867 & 0.9779 & 0.9644 & 0.9108 & 0.8773 & 0.8922 & 0.8948 \\
\hline $\mathrm{SH}$ & 0.7763 & 0.8137 & 0.8289 & 0.8504 & 0.9023 & 0.9425 & 0.9683 & 1.0000 & 0.9995 & 0.9984 & 1.0000 & 1.0000 \\
\hline JS & 0.7933 & 0.7744 & 0.7595 & 0.8013 & 0.8704 & 0.9320 & 0.9755 & 1.0000 & 0.9791 & 1.0000 & 0.8700 & 0.8888 \\
\hline ZJ & 0.8025 & 0.8173 & 0.8073 & 0.8404 & 0.8652 & 0.9089 & 0.9383 & 0.9671 & 0.8534 & 0.8574 & 0.8613 & 0.9073 \\
\hline $\mathrm{AH}$ & 0.7713 & 0.7876 & 0.7903 & 0.7994 & 0.8097 & 0.8348 & 0.8305 & 0.8419 & 0.7867 & 0.8057 & 0.7745 & 0.7993 \\
\hline FJ & 0.9300 & 0.9150 & 0.8249 & 0.8275 & 0.8636 & 0.8628 & 0.8580 & 0.8846 & 0.7629 & 0.8023 & 0.8216 & 0.8616 \\
\hline JX & 0.7647 & 0.7359 & 0.7371 & 0.7214 & 0.7060 & 0.7214 & 0.7174 & 0.7199 & 0.6885 & 0.6912 & 0.6941 & 0.7110 \\
\hline SD & 0.8920 & 0.9006 & 0.8938 & 0.8853 & 0.8759 & 0.8638 & 0.8985 & 0.9283 & 0.8981 & 0.9060 & 0.8939 & 0.9280 \\
\hline HEN & 0.8293 & 0.8352 & 0.8240 & 0.8184 & 0.7883 & 0.7573 & 0.6880 & 0.6629 & 0.6559 & 0.6477 & 0.6569 & 0.6671 \\
\hline HUB & 0.6332 & 0.6557 & 0.6772 & 0.6992 & 0.7129 & 0.7250 & 0.7310 & 0.7439 & 0.7250 & 0.7250 & 0.7289 & 0.7405 \\
\hline HUN & 0.8049 & 0.7913 & 0.7673 & 0.7663 & 0.7690 & 0.7842 & 0.7820 & 0.7808 & 0.7636 & 0.7443 & 0.7547 & 0.8002 \\
\hline GD & 0.9981 & 1.0000 & 0.9932 & 1.0000 & 1.0000 & 1.0000 & 1.0000 & 1.0000 & 1.0000 & 1.0000 & 1.0000 & 0.9951 \\
\hline GX & 0.7722 & 0.7382 & 0.7014 & 0.6643 & 0.6337 & 0.6330 & 0.5830 & 0.5475 & 0.5546 & 0.5835 & 0.6009 & 0.6620 \\
\hline HAN & 0.6024 & 0.6525 & 0.7023 & 0.8030 & 0.8702 & 0.8133 & 0.8169 & 0.8097 & 0.7806 & 0.7664 & 0.8072 & 0.8102 \\
\hline CQ & 0.6961 & 0.6508 & 0.6274 & 0.6180 & 0.6747 & 0.6934 & 0.7174 & 0.7877 & 0.8094 & 0.8348 & 0.8482 & 0.8705 \\
\hline SC & 0.6603 & 0.6828 & 0.6937 & 0.7492 & 0.7597 & 0.7581 & 0.7826 & 0.8136 & 0.8172 & 0.8282 & 0.8106 & 0.7994 \\
\hline GZ & 0.6069 & 0.6219 & 0.6383 & 0.6677 & 0.6888 & 0.6930 & 0.6893 & 0.7123 & 0.6702 & 0.6439 & 0.6519 & 0.6031 \\
\hline YN & 0.7927 & 0.7762 & 0.7882 & 0.8060 & 0.8129 & 0.8365 & 0.8121 & 0.7770 & 0.6285 & 0.6286 & 0.6333 & 0.6354 \\
\hline SAX & 0.7328 & 0.7418 & 0.7267 & 0.7272 & 0.6899 & 0.6921 & 0.6962 & 0.7056 & 0.7088 & 0.7093 & 0.7153 & 0.7086 \\
\hline GS & 0.7509 & 0.7790 & 0.8005 & 0.8191 & 0.8222 & 0.8021 & 0.7835 & 0.7834 & 0.7615 & 0.7731 & 0.7803 & 0.7812 \\
\hline $\mathrm{QH}$ & 0.5510 & 0.5066 & 0.4441 & 0.5359 & 0.5025 & 0.5425 & 0.5196 & 0.5411 & 0.5700 & 0.5776 & 0.6080 & 0.6254 \\
\hline NX & 0.4429 & 0.4282 & 0.3284 & 0.4122 & 0.3355 & 0.3465 & 0.3363 & 0.3415 & 0.3634 & 0.3939 & 0.4202 & 0.4577 \\
\hline $\mathrm{XJ}$ & 0.6210 & 0.6166 & 0.6178 & 0.6645 & 0.6423 & 0.6466 & 0.6518 & 0.6476 & 0.6760 & 0.6497 & 0.6243 & 0.6166 \\
\hline
\end{tabular}


Table 4. Unified efficiency scores under managerial disposability.

\begin{tabular}{|c|c|c|c|c|c|c|c|c|c|c|c|c|}
\hline Province & 2003 & 2004 & 2005 & 2006 & 2007 & 2008 & 2009 & 2010 & 2011 & 2012 & 2013 & 2014 \\
\hline BJ & 1.0000 & 0.9910 & 0.9821 & 0.9719 & 1.0000 & 1.0000 & 0.9978 & 1.0000 & 1.0000 & 1.0000 & 1.0000 & 1.0000 \\
\hline TJ & 0.8565 & 0.8544 & 0.7463 & 0.8150 & 0.8886 & 0.9269 & 1.0000 & 1.0000 & 1.0000 & 1.0000 & 1.0000 & 1.0000 \\
\hline HEB & 0.6551 & 0.6279 & 0.7050 & 0.7482 & 0.8493 & 0.9094 & 0.9457 & 1.0000 & 0.7586 & 0.7694 & 0.7682 & 0.7842 \\
\hline $\mathrm{SX}$ & 0.8507 & 0.8619 & 0.9162 & 0.9876 & 0.9617 & 0.9498 & 0.9590 & 0.9766 & 0.9481 & 0.9109 & 0.9366 & 0.9331 \\
\hline IM & 0.9787 & 0.9778 & 0.9721 & 1.0000 & 1.0000 & 0.9699 & 1.0000 & 1.0000 & 0.9950 & 1.0000 & 1.0000 & 1.0000 \\
\hline LN & 0.7299 & 0.7390 & 0.7378 & 0.7364 & 0.7329 & 0.7950 & 0.8271 & 0.8742 & 0.8217 & 0.8361 & 0.8311 & 0.8031 \\
\hline $\mathrm{JL}$ & 0.9765 & 0.7253 & 0.5905 & 0.6629 & 0.6379 & 0.6446 & 0.6831 & 0.7196 & 0.6870 & 0.7225 & 0.7784 & 0.7852 \\
\hline HLJ & 0.8689 & 0.8974 & 1.0000 & 0.9473 & 0.9821 & 0.9501 & 0.9659 & 0.9231 & 0.8186 & 0.8136 & 0.8372 & 0.8358 \\
\hline $\mathrm{SH}$ & 0.7537 & 0.7276 & 0.7667 & 0.7907 & 0.8289 & 0.8717 & 0.8848 & 0.8987 & 0.9764 & 0.9959 & 1.0000 & 0.9694 \\
\hline JS & 0.5836 & 0.5566 & 0.5655 & 0.5856 & 0.6436 & 0.6847 & 0.7305 & 0.7746 & 0.6725 & 0.7091 & 0.7511 & 0.7777 \\
\hline ZJ & 0.6641 & 0.6166 & 0.6091 & 0.6391 & 0.6604 & 0.7060 & 0.7576 & 0.7931 & 0.6943 & 0.7288 & 0.7575 & 0.7935 \\
\hline $\mathrm{AH}$ & 0.5184 & 0.5078 & 0.5749 & 0.5571 & 0.5656 & 0.5757 & 0.5737 & 0.6109 & 0.5701 & 0.5569 & 0.5677 & 0.5961 \\
\hline FJ & 0.6228 & 0.5951 & 0.6316 & 0.6365 & 0.6303 & 0.6596 & 0.6489 & 0.7086 & 0.6037 & 0.6985 & 0.7291 & 0.7694 \\
\hline JX & 0.5999 & 0.5304 & 0.5840 & 0.5577 & 0.5408 & 0.5755 & 0.5934 & 0.5882 & 0.5599 & 0.5831 & 0.5827 & 0.6099 \\
\hline SD & 0.7267 & 0.7127 & 0.7632 & 0.7973 & 0.8460 & 0.8930 & 0.9517 & 1.0000 & 0.7847 & 0.8036 & 0.7907 & 0.7905 \\
\hline $\mathrm{HEN}$ & 0.6171 & 0.6090 & 0.5967 & 0.6090 & 0.6066 & 0.6427 & 0.6551 & 0.7064 & 0.6495 & 0.6797 & 0.6729 & 0.6909 \\
\hline HUB & 0.5802 & 0.6273 & 0.6257 & 0.6140 & 0.6211 & 0.6631 & 0.6830 & 0.7053 & 0.6867 & 0.7279 & 0.7113 & 0.7235 \\
\hline HUN & 0.6060 & 0.6523 & 0.6556 & 0.6540 & 0.6624 & 0.7298 & 0.7391 & 0.7568 & 0.8060 & 0.8170 & 0.7302 & 0.7384 \\
\hline GD & 0.6517 & 0.6778 & 0.6973 & 0.7097 & 0.7309 & 0.7608 & 0.7815 & 0.7965 & 0.7559 & 0.8039 & 0.7874 & 0.8049 \\
\hline GX & 0.6270 & 0.6070 & 0.6204 & 0.5952 & 0.5800 & 0.6195 & 0.5975 & 0.5798 & 0.5759 & 0.5760 & 0.5963 & 0.6447 \\
\hline HAN & 0.5794 & 0.4892 & 0.6193 & 0.8841 & 1.0000 & 0.7582 & 0.6858 & 0.7834 & 0.8411 & 0.8496 & 0.8624 & 0.8392 \\
\hline CQ & 0.6392 & 0.6197 & 0.7527 & 0.7413 & 0.7508 & 0.6950 & 0.7055 & 0.7885 & 0.8511 & 0.8891 & 0.8194 & 0.8410 \\
\hline SC & 0.7353 & 0.6894 & 0.7833 & 0.7804 & 0.7822 & 0.7822 & 0.8047 & 0.8160 & 0.8802 & 0.9624 & 0.8637 & 0.8585 \\
\hline GZ & 0.8301 & 0.8642 & 0.8164 & 0.8864 & 0.8973 & 0.9155 & 0.9350 & 1.0000 & 0.8284 & 0.8071 & 0.7894 & 0.7294 \\
\hline $\mathrm{YN}$ & 0.7844 & 0.9724 & 0.7478 & 0.7789 & 0.8031 & 0.8314 & 0.8812 & 0.8968 & 0.6353 & 0.6705 & 0.6749 & 0.7140 \\
\hline SAX & 0.8994 & 0.8510 & 0.8157 & 0.8342 & 0.7414 & 0.7226 & 0.7153 & 0.7335 & 0.7454 & 0.7563 & 0.8551 & 0.8189 \\
\hline GS & 0.8523 & 0.8979 & 0.9515 & 1.0000 & 0.9930 & 0.9488 & 0.9315 & 0.9122 & 0.8448 & 0.8560 & 0.9303 & 0.9237 \\
\hline $\mathrm{QH}$ & 0.8890 & 0.9251 & 1.0000 & 0.9328 & 0.9567 & 0.9046 & 0.8822 & 0.9515 & 1.0000 & 1.0000 & 1.0000 & 1.0000 \\
\hline $\bar{N} X$ & 0.6432 & 0.7712 & 0.6241 & 0.7098 & 0.8239 & 0.8413 & 0.8476 & 0.6817 & 0.6797 & 0.7433 & 0.7484 & 0.7850 \\
\hline$X \mathrm{~J}$ & 0.9061 & 0.8851 & 0.8747 & 0.9601 & 0.8539 & 0.8110 & 0.7905 & 0.7810 & 0.8567 & 0.8379 & 0.8714 & 0.9063 \\
\hline
\end{tabular}


Table 5. Unified efficiency under natural disposability and window analysis.

\begin{tabular}{|c|c|c|c|c|c|c|c|c|c|c|c|}
\hline \multirow{2}{*}{ Province } & \multicolumn{10}{|c|}{ Windows } & \multirow{2}{*}{ Average } \\
\hline & 2003-2005 & 2004-2006 & 2005-2007 & 2006-2008 & 2007-2009 & 2008-2010 & 2009-2011 & 2010-2012 & 2011-2013 & 2012-2014 & \\
\hline BJ & 1.0000 & 1.0000 & 1.0000 & 1.0000 & 1.0000 & 1.0000 & 1.0000 & 1.0000 & 1.0000 & 1.0000 & 1.0000 \\
\hline $\mathrm{TJ}$ & 1.0000 & 1.0000 & 1.0000 & 1.0000 & 1.0000 & 1.0000 & 1.0000 & 1.0000 & 1.0000 & 1.0000 & 1.0000 \\
\hline HEB & 0.9334 & 0.9244 & 0.9151 & 0.8799 & 0.8616 & 0.8640 & 0.8532 & 0.8301 & 0.8467 & 0.8483 & 0.8757 \\
\hline $\mathrm{SX}$ & 0.8816 & 0.8795 & 0.8421 & 0.8146 & 0.7557 & 0.7344 & 0.7375 & 0.7179 & 0.7007 & 0.6960 & 0.7760 \\
\hline IM & 0.9958 & 1.0000 & 1.0000 & 0.9667 & 0.9370 & 0.8789 & 0.9421 & 0.9959 & 0.9557 & 0.9434 & 0.9616 \\
\hline LN & 0.8672 & 0.8697 & 0.8500 & 0.8551 & 0.8614 & 0.8758 & 0.8618 & 0.8592 & 0.8663 & 0.8461 & 0.8613 \\
\hline $\mathrm{JL}$ & 0.8679 & 0.8530 & 0.7810 & 0.7315 & 0.7260 & 0.7292 & 0.7470 & 0.8146 & 0.7582 & 0.7537 & 0.7762 \\
\hline HLJ & 1.0000 & 1.0000 & 1.0000 & 1.0000 & 1.0000 & 1.0000 & 0.9483 & 0.9155 & 0.9119 & 0.9086 & 0.9684 \\
\hline $\mathrm{SH}$ & 1.0000 & 1.0000 & 1.0000 & 1.0000 & 1.0000 & 1.0000 & 1.0000 & 1.0000 & 1.0000 & 1.0000 & 1.0000 \\
\hline JS & 1.0000 & 0.9723 & 1.0000 & 1.0000 & 1.0000 & 1.0000 & 1.0000 & 1.0000 & 0.8997 & 0.8884 & 0.9760 \\
\hline ZJ & 0.9789 & 0.9942 & 0.9698 & 0.9792 & 0.9814 & 0.9654 & 0.9087 & 0.9152 & 0.9202 & 0.9070 & 0.9520 \\
\hline $\mathrm{AH}$ & 0.8622 & 0.8474 & 0.8466 & 0.8595 & 0.8584 & 0.8743 & 0.8153 & 0.8185 & 0.7935 & 0.7996 & 0.8375 \\
\hline $\mathrm{FJ}$ & 0.8865 & 0.8791 & 0.9156 & 0.9199 & 0.9028 & 0.8860 & 0.8089 & 0.8473 & 0.8902 & 0.8614 & 0.8798 \\
\hline $\mathrm{JX}$ & 0.8193 & 0.7859 & 0.7597 & 0.7646 & 0.7678 & 0.7682 & 0.7281 & 0.7229 & 0.7124 & 0.7115 & 0.7540 \\
\hline SD & 1.0000 & 0.9794 & 0.9582 & 0.9480 & 0.9349 & 0.9304 & 0.9086 & 0.9116 & 0.9158 & 0.9287 & 0.9416 \\
\hline HEN & 0.8913 & 0.8709 & 0.8333 & 0.7994 & 0.7475 & 0.7180 & 0.6882 & 0.6734 & 0.6682 & 0.6682 & 0.7558 \\
\hline HUB & 0.7497 & 0.7508 & 0.7522 & 0.7501 & 0.7620 & 0.7803 & 0.7684 & 0.7621 & 0.7519 & 0.7466 & 0.7574 \\
\hline HUN & 0.7782 & 0.7931 & 0.7941 & 0.7951 & 0.7967 & 0.8030 & 0.8004 & 0.7665 & 0.7760 & 0.8003 & 0.7903 \\
\hline GD & 1.0000 & 1.0000 & 1.0000 & 1.0000 & 1.0000 & 1.0000 & 1.0000 & 1.0000 & 1.0000 & 0.9944 & 0.9994 \\
\hline GX & 0.7176 & 0.6925 & 0.6627 & 0.6576 & 0.6329 & 0.6168 & 0.6290 & 0.6423 & 0.6506 & 0.6617 & 0.6564 \\
\hline HAN & 1.0000 & 1.0000 & 0.9962 & 0.9717 & 0.9895 & 0.9446 & 0.8451 & 0.8280 & 0.8366 & 0.8101 & 0.9222 \\
\hline CQ & 0.7374 & 0.7258 & 0.7527 & 0.7504 & 0.7579 & 0.8371 & 0.8609 & 0.8808 & 0.8728 & 0.8771 & 0.8053 \\
\hline SC & 0.7740 & 0.8062 & 0.8034 & 0.7866 & 0.8145 & 0.8509 & 0.8586 & 0.8606 & 0.8319 & 0.7996 & 0.8186 \\
\hline GZ & 0.7192 & 0.7437 & 0.7368 & 0.7404 & 0.7336 & 0.7436 & 0.7054 & 0.6804 & 0.6660 & 0.6228 & 0.7092 \\
\hline $\mathrm{YN}$ & 0.8747 & 0.8756 & 0.8627 & 0.8760 & 0.8632 & 0.8164 & 0.6735 & 0.6602 & 0.6446 & 0.6458 & 0.7793 \\
\hline SAX & 0.8136 & 0.8101 & 0.7506 & 0.7414 & 0.7255 & 0.7141 & 0.7122 & 0.7169 & 0.7147 & 0.7318 & 0.7431 \\
\hline GS & 0.8648 & 0.8742 & 0.8538 & 0.8318 & 0.8217 & 0.8246 & 0.7991 & 0.8107 & 0.7972 & 0.8016 & 0.8279 \\
\hline $\mathrm{QH}$ & 0.6212 & 0.6782 & 0.5842 & 0.5855 & 0.5405 & 0.5747 & 0.5744 & 0.5882 & 0.6231 & 0.6252 & 0.5995 \\
\hline $\mathrm{NX}$ & 0.4142 & 0.5125 & 0.3840 & 0.3911 & 0.3441 & 0.3742 & 0.3670 & 0.4048 & 0.4320 & 0.4575 & 0.4081 \\
\hline XJ & 0.7389 & 0.7825 & 0.6985 & 0.6925 & 0.6843 & 0.6729 & 0.6904 & 0.6710 & 0.6291 & 0.6438 & 0.6904 \\
\hline
\end{tabular}


Table 6. Unified efficiency under managerial disposability and window analysis.

\begin{tabular}{|c|c|c|c|c|c|c|c|c|c|c|c|}
\hline \multirow{2}{*}{ Province } & \multicolumn{10}{|c|}{ Windows } & \multirow{2}{*}{ Average } \\
\hline & 2003-2005 & 2004-2006 & 2005-2007 & 2006-2008 & 2007-2009 & 2008-2010 & 2009-2011 & 2010-2012 & 2011-2013 & 2012-2014 & \\
\hline BJ & 1.0000 & 1.0000 & 1.0000 & 1.0000 & 1.0000 & 1.0000 & 1.0000 & 1.0000 & 1.0000 & 1.0000 & 1.0000 \\
\hline $\mathrm{TJ}$ & 0.9685 & 1.0000 & 1.0000 & 1.0000 & 1.0000 & 1.0000 & 1.0000 & 1.0000 & 1.0000 & 1.0000 & 0.9968 \\
\hline HEB & 1.0000 & 1.0000 & 1.0000 & 1.0000 & 0.9607 & 1.0000 & 0.8189 & 0.7971 & 0.7827 & 0.7844 & 0.9144 \\
\hline $\mathrm{SX}$ & 1.0000 & 1.0000 & 1.0000 & 1.0000 & 0.9991 & 1.0000 & 0.9911 & 0.9646 & 1.0000 & 1.0000 & 0.9955 \\
\hline IM & 1.0000 & 1.0000 & 1.0000 & 1.0000 & 1.0000 & 1.0000 & 1.0000 & 1.0000 & 1.0000 & 1.0000 & 1.0000 \\
\hline LN & 0.8374 & 0.8506 & 0.8429 & 0.9076 & 0.9181 & 0.9428 & 0.8296 & 0.8460 & 0.8421 & 0.8029 & 0.8620 \\
\hline $\mathrm{JL}$ & 0.7426 & 0.8152 & 0.7873 & 0.8028 & 0.7859 & 0.7735 & 0.6868 & 0.7651 & 0.7801 & 0.7853 & 0.7725 \\
\hline HLJ & 1.0000 & 0.9897 & 1.0000 & 1.0000 & 1.0000 & 1.0000 & 0.8449 & 0.8298 & 0.8541 & 0.8354 & 0.9354 \\
\hline $\mathrm{SH}$ & 1.0000 & 0.9661 & 0.9176 & 0.9214 & 0.9225 & 0.9267 & 1.0000 & 1.0000 & 1.0000 & 1.0000 & 0.9654 \\
\hline JS & 0.6808 & 0.6785 & 0.6963 & 0.7274 & 0.7580 & 0.7737 & 0.7390 & 0.7518 & 0.7663 & 0.7774 & 0.7349 \\
\hline ZJ & 0.7584 & 0.7992 & 0.7619 & 0.7698 & 0.7868 & 0.7961 & 0.7665 & 0.7718 & 0.7796 & 0.7932 & 0.7783 \\
\hline $\mathrm{AH}$ & 0.6806 & 0.6634 & 0.6508 & 0.6738 & 0.6584 & 0.6851 & 0.6086 & 0.6014 & 0.5903 & 0.5959 & 0.6408 \\
\hline $\mathrm{FJ}$ & 0.7746 & 0.7647 & 0.7259 & 0.7104 & 0.6977 & 0.7389 & 0.6516 & 0.7372 & 0.7513 & 0.7691 & 0.7322 \\
\hline JX & 0.6717 & 0.6398 & 0.6107 & 0.6369 & 0.6527 & 0.6461 & 0.5967 & 0.5981 & 0.5969 & 0.6095 & 0.6259 \\
\hline SD & 1.0000 & 1.0000 & 0.9931 & 1.0000 & 0.9612 & 1.0000 & 0.7916 & 0.8031 & 0.8031 & 0.7898 & 0.9142 \\
\hline HEN & 0.7269 & 0.7250 & 0.7057 & 0.7235 & 0.7105 & 0.7414 & 0.6588 & 0.6785 & 0.6837 & 0.6905 & 0.7045 \\
\hline HUB & 0.6848 & 0.6884 & 0.6975 & 0.7293 & 0.7437 & 0.7389 & 0.6899 & 0.7263 & 0.7128 & 0.7255 & 0.7137 \\
\hline HUN & 0.6850 & 0.6835 & 0.6908 & 0.7758 & 0.7867 & 0.8084 & 0.8128 & 0.8143 & 0.7298 & 0.7429 & 0.7530 \\
\hline GD & 0.8648 & 0.8625 & 0.8511 & 0.8377 & 0.8367 & 0.8366 & 0.7959 & 0.8003 & 0.8066 & 0.8054 & 0.8298 \\
\hline GX & 0.6857 & 0.6581 & 0.5992 & 0.6404 & 0.6249 & 0.6188 & 0.5920 & 0.5847 & 0.6165 & 0.6444 & 0.6265 \\
\hline HAN & 1.0000 & 1.0000 & 1.0000 & 1.0000 & 1.0000 & 0.8421 & 0.8796 & 0.8611 & 0.8623 & 0.8391 & 0.9284 \\
\hline CQ & 0.8014 & 0.7922 & 0.8053 & 0.7285 & 0.7417 & 0.8426 & 0.8571 & 0.8881 & 0.8298 & 0.8447 & 0.8131 \\
\hline SC & 0.8183 & 0.8230 & 0.8507 & 0.8583 & 0.8754 & 0.8760 & 0.8847 & 0.9591 & 0.8630 & 0.8683 & 0.8677 \\
\hline GZ & 0.9528 & 1.0000 & 0.9378 & 0.9663 & 0.9449 & 1.0000 & 0.8405 & 0.8206 & 0.8172 & 0.7732 & 0.9053 \\
\hline $\mathrm{YN}$ & 0.9735 & 0.9551 & 0.8837 & 0.9125 & 0.8862 & 0.9099 & 0.6444 & 0.6717 & 0.6805 & 0.7228 & 0.8240 \\
\hline SAX & 0.8412 & 0.8450 & 0.7721 & 0.7793 & 0.7592 & 0.7779 & 0.7718 & 0.7679 & 0.8638 & 0.8477 & 0.8026 \\
\hline GS & 1.0000 & 1.0000 & 1.0000 & 1.0000 & 0.9970 & 0.9783 & 0.8677 & 0.8784 & 0.9702 & 0.9980 & 0.9690 \\
\hline $\mathrm{QH}$ & 1.0000 & 1.0000 & 1.0000 & 1.0000 & 0.9862 & 1.0000 & 1.0000 & 1.0000 & 1.0000 & 1.0000 & 0.9986 \\
\hline $\mathrm{NX}$ & 0.8412 & 0.9396 & 0.9180 & 0.9099 & 0.8486 & 0.7485 & 0.6863 & 0.7664 & 0.7709 & 0.8088 & 0.8238 \\
\hline XJ & 1.0000 & 0.9973 & 0.9082 & 0.8878 & 0.8739 & 0.8851 & 0.8982 & 0.8741 & 0.8917 & 0.9390 & 0.9155 \\
\hline
\end{tabular}




\section{Conclusions}

Natural and managerial disposability are two important strategic concepts, whose priorities are economic prosperity and environmental protection, respectively. This study defines social sustainability as the simultaneous achievement of economic prosperity and environmental protection, and then assesses the degree of social sustainability across provinces in China. In addition, this study combines the concepts of natural and managerial disposability with DEA window analysis. The proposed method allows for frontier shifts among different time periods and thus can provide more stable and reliable results. This method is applied to assess the energy and environmental performances across provinces in China during 2003-2014, and provides detailed information about provincial variations, which are valuable and crucial to policy makers (especially for those in provincial governments). This type of study has never been performed in the previous analyses of China's environmental assessment.

The main findings are reported. First, there are no significant improvements in China's environmental performance during the analysis period. Historically, economic prosperity is the major target, and the Chinese government neglects environmental protection. Looking ahead, the Chinese government should pay great attention to environmental protection and promote social sustainability.

Second, there are increasing trends in the provincial gaps regarding the unified efficiency under natural or managerial disposability. Regional imbalances will be a major barrier for the Chinese government to promote social sustainability. In the future, the central government should allocate more resources to the underdeveloped provinces to help them protect the environment. Reducing regional imbalances contributes to social sustainability.

Third, the concepts of natural and managerial disposability are quite meaningful. In particular, there is a large potential for some provinces to improve their unified efficiency under managerial disposability. The underlying policy implication for business leaders and policy makers is that significant contributions can be made by eco-technology progress combined with managerial performance improvements. This can be a new policy direction for the Chinese government.

Acknowledgments: The authors are grateful to the anonymous referees for their valuable suggestions. This paper is supported by the National Natural Foundation of China (Grant No. 71403147), the Ministry of Education Research of Social Sciences Youth Funded Projects (Grant No. 13YJC790065), the Shandong Social Science Planning Fund Program (Grant No. 12DJJJ12), and the Young Scholars Program of Shandong University (Grant No. 2016WLJH02).

Author Contributions: For research articles with several authors, a short paragraph specifying their individual contributions must be provided. The following statements should be used " Toshiyuki Sueyoshi and Yan Yuan conceived the idea and developed the model, Daoping Wang collected the data and finished the programing, Aijun Li analyzed the results and wrote the paper." Authorship must be limited to those who have contributed substantially to the work reported.

Conflicts of Interest: The authors declare no conflict of interest.

\section{References}

1. IEA. $\mathrm{CO}_{2}$ Emissions from Fuel Combustion Highlights 2016. Available online: http://bbs.pinggu.org/ thread-5418823--1-1.html (accessed on 21 November 2016).

2. China Statistics Press. China Statistical Yearbook on Environment; China Statistics Press: Beijing, China, 2005-2015. Available online: http:/ / navi.cnki.net/KNavi/YearbookDetail?pcode=CYFD\&pykm=YHJSD (accessed on 8 November 2016).

3. Szopik-Depczyńska, K.; Cheba, K.; Bąk, I.; Kiba-Janiak, M.; Saniuk, S.; Dembińska, I.; Ioppolo, G. The application of relative taxonomy to the study of disproportions in the area of sustainable development of the European Union. Land Use Policy 2017, 68, 481-491. [CrossRef]

4. Sueyoshi, T.; Goto, M. DEA radial measurement for environmental assessment: A comparative study between Japanese chemical and pharmaceutical firms. Appl. Energy 2014, 115, 502-513. [CrossRef] 
5. Sueyoshi, T.; Goto, M. Environmental assessment for corporate sustainability by resource utilization and technology innovation: DEA radial measurement on Japanese industrial sectors. Energy Econ. 2014, 46, 295-307. [CrossRef]

6. Bowlin, W.F. Evaluating the Efficiency of US Air Force Real-Property Maintenance Activities. J. Oper. Res. Soc. 1987, 38, 127-135. [CrossRef]

7. Taddeo, R.; Simboli, A.; Ioppolo, G.; Morgante, A. Industrial symbiosis, Networking and innovation: The potential role of innovation poles. Sustainability 2017, 9, 169. [CrossRef]

8. Arbolino, R.; Carlucci, F.; Cirà, A.; Ioppolo, G.; Yigitcanlar, T. Efficiency of the EU regulation on greenhouse gas emissions in Italy: The hierarchical cluster analysis approach. Ecol. Indic. 2017, 81, 115-123. [CrossRef]

9. Thore, S.; Kozmetsky, G.; Phillips, F. DEA of Financial Statements Data: The U.S. Computer Industry. J. Prod. Anal. 1994, 5, 229-248. [CrossRef]

10. Goto, M.; Tsutsui, M. Comparison of Productive and Cost Efficiencies among Japanese and US Electric Utilities. Omega 1998, 26, 177-194. [CrossRef]

11. Sueyoshi, T.; Aoki, S. A use of a nonparametric statistic for DEA frontier shift: The Kruskal and Wallis rank test. Omega 2001, 29, 1-18. [CrossRef]

12. Sueyoshi, T.; Goto, M.; Sugiyama, M. DEA Window analysis for environmental assessment in a dynamic time shift: Performance assessment of U.S. coal-fired power plants. Energy Econ. 2013, 40, 845-857. [CrossRef]

13. Yang, W.C.; Lee, Y.M.; Hu, J.L. Urban sustainability assessment of Taiwan based on data envelopment analysis. Renew. Sustain. Energy Rev. 2016, 61, 341-353. [CrossRef]

14. Vlontzos, G.; Pardalos, P.M. Assess and prognosticate green house gas emissions from agricultural production of EU countries, by implementing, DEA Window analysis and artificial neural networks. Renew. Sustain. Energy Rev. 2017, 76, 155-162. [CrossRef]

15. Sueyoshi, T.; Goto, M. DEA radial and non-radial models for unified efficiency under natural and managerial disposability: Theoretical extension by strong complementary slackness conditions. Energy Econ. 2012, 34, 700-713. [CrossRef]

16. Sueyoshi, T.; Goto, M. Undesirable congestion under natural disposability and desirable congestion under managerial disposability in U.S. electric power industry measured by DEA environmental assessment. Energy Econ. 2016, 55, 173-188. [CrossRef]

17. Sueyoshi, T.; Yuan, Y. Marginal Rate of Transformation and Rate of Substitution measured by DEA environmental assessment: Comparison among European and North American nations. Energy Econ. 2016, 56, 270-287. [CrossRef]

18. Sueyoshi, T.; Yuan, Y.; Goto, M. A literature study for DEA applied to energy and environment. Energy Econ. 2017, 62, 104-124. [CrossRef]

19. Färe, R.; Grosskopf, S.; Lovell, C.A.K.; Pasurka, C. Multilateral productivity comparisons when some outputs are undesirable: A nonparametric approach. Rev. Econ. Stat. 1989, 71, 90-98. [CrossRef]

20. Yao, X.; Zhou, H.C.; Zhang, A.Z.; Li, A.J. Regional energy efficiency, carbon emission performance and technology gaps in China: A meta-frontier non-radial directional distance function analysis. Energy Policy 2015, 84, 142-154. [CrossRef]

21. Li, A.J.; Zhang, A.Z.; Zhou, Y.X.; Yao, X. Decomposition analysis of factors affecting carbon dioxide emissions across provinces in China. J. Clean. Prod. 2017, 141, 1428-1444. [CrossRef]

22. Sueyoshi, T.; Goto, M. A comparative study among fossil fuel power plants in PJM and California ISO by DEA environmental assessment. Energy Econ. 2013, 40, 130-145. [CrossRef]

23. Sueyoshi, T.; Goto, M. Data envelopment analysis for environmental assessment: Comparison between public and private ownership in petroleum industry. Eur. J. Oper. Res. 2012, 216, 668-678. [CrossRef]

24. Sueyoshi, T.; Goto, M. DEA environmental assessment in a time horizon: Malmquist index on fuel mix, electricity and $\mathrm{CO}_{2}$ of industrial nations. Energy Econ. 2013, 40, 370-382. [CrossRef]

25. Sueyoshi, T.; Goto, M. DEA environmental assessment of coal fired power plants: Methodological comparison between radial and non-radial models. Energy Econ. 2012, 34, 1854-1863. [CrossRef]

26. Sueyoshi, T.; Goto, M. Japanese fuel mix strategy after disaster of Fukushima Daiichi nuclear power plant: Lessons from international comparison among industrial nations measured by DEA environmental assessment in time horizon. Energy Econ. 2015, 52, 87-103. [CrossRef] 
27. Sueyoshi, T.; Yuan, Y. Returns to damage under undesirable congestion and damages to return under desirable congestion measured by DEA environmental assessment with multiplier restriction: Economic and energy planning for social sustainability in China. Energy Econ. 2016, 56, 288-309. [CrossRef]

28. Sueyoshi, T.; Yuan, Y. Social sustainability measured by intermediate approach for DEA environmental assessment: Chinese regional planning for economic development and pollution prevention. Energy Econ. 2017, 66, 154-166. [CrossRef]

29. Sueyoshi, T.; Yuan, Y.; Li, A.; Wang, D. Methodological comparison among Radial, Non-radial and Intermediate approaches for DEA environmental assessment. Energy Econ. 2017, 67, 439-453. [CrossRef]

30. Sueyoshi, T.; Goto, M.; Wang, D. Malmquist index measurement for sustainability enhancement in Chinese municipalities and provinces. Energy Econ. 2017, 67, 554-571. [CrossRef]

31. Sueyoshi, T.; Yuan, Y. China's regional sustainability and diversified resource allocation: DEA environmental assessment on economic development and air pollution. Energy Econ. 2015, 49, 239-256. [CrossRef]

32. Zhou, P.; Ang, B.W.; Poh, K.L. A survey of data envelopment analysis in energy and environmental studies. Eur. J. Oper. Res. 2008, 189, 1-18. [CrossRef]

33. Zhang, N.; Choi, Y. A note on the evolution of directional distance function and its development in energy and environmental studies 1997-2013. Renew. Sustain. Energy Rev. 2014, 33, 50-59. [CrossRef]

34. Wang, K.; Wei, Y.M.; Zhang, X. A comparative analysis of China's regional energy and emission performance: Which is the better way to deal with undesirable outputs? Energy Policy 2012, 46, 574-584. [CrossRef]

35. Wei, C.; Ni, J.L.; Du, L.M. Regional allocation of carbon dioxide abatement in China. China Econ. Rev. 2012, 23, 552-565. [CrossRef]

36. Wu, F.; Fan, L.W.; Zhou, P.; Zhou, D.Q. Industrial energy efficiency with $\mathrm{CO}_{2}$ emissions in China: A nonparametric analysis. Energy Policy 2012, 49, 164-172. [CrossRef]

37. Wang, Q.W.; Zhao, Z.Y.; Zhou, P.; Zhou, D.Q. Energy efficiency and production technology heterogeneity in China: A meta-frontier DEA approach. Econ. Modell. 2013, 35, 283-289. [CrossRef]

38. Wang, Z.H.; Feng, C.; Zhang, B. An empirical analysis of China's energy efficiency from both static and dynamic perspectives. Energy 2014, 74, 322-330. [CrossRef]

39. Wang, K.; Wei, Y.M. China's regional industrial energy efficiency and carbon emissions abatement costs. Appl. Energy 2014, 130, 617-631. [CrossRef]

40. Wu, J.; An, Q.X.; Yao, X.; Wang, B. Environmental efficiency evaluation of industry in China based on a new fixed sum undesirable output data envelopment analysis. J. Clean. Prod. 2014, 74, 96-104. [CrossRef]

41. Zhou, P.; Sun, Z.R.; Zhou, D.Q. Optimal path for controlling $\mathrm{CO}_{2}$ emissions in China: A perspective of efficiency analysis. Energy Econ. 2014, 45, 99-110. [CrossRef]

42. Li, K.; Lin, B.Q. Metafroniter energy efficiency with $\mathrm{CO}_{2}$ emissions and its convergence analysis for China. Energy Econ. 2015, 48, 230-241. [CrossRef]

43. Wu, J.; Yin, P.Z.; Sun, J.S.; Chu, J.F.; Liang, L. Evaluating the environmental efficiency of a two-stage system with undesired outputs by a DEA approach: An interest preference perspective. Eur. J. Oper. Res. 2016, 254, 1047-1062. [CrossRef]

44. Zhang, Y.J.; Hao, J.F.; Song, J. The $\mathrm{CO}_{2}$ emission efficiency, reduction potential and spatial clustering in China's industry: Evidence from the regional level. Appl. Energy 2016, 174, 213-223. [CrossRef]

45. Du, H.B.; Matisoff, D.C.; Wang, Y.Y.; Liu, X. Understanding drivers of energy efficiency changes in China. Appl. Energy 2016, 184, 1196-1206. [CrossRef]

46. Long, R.Y.; Wang, H.Z.; Chen, H. Regional differences and pattern classifications in the efficiency of coal consumption in China. J. Clean. Prod. 2016, 112, 3684-3691. [CrossRef]

47. Chen, L.; Jia, G.Z. Environmental efficiency analysis of China's regional industry: A data envelopment analysis (DEA) based approach. J. Clean. Prod. 2017, 142, 846-853. [CrossRef]

48. Du, J.; Chen, Y.; Huang, Y. A Modified Malmquist-Luenberger Productivity Index: Assessing Environmental Productivity Performance in China. Eur. J. Oper. Res. 2017, in press. [CrossRef]

49. Feng, C.; Zhang, H.; Huang, J.B. The approach to realizing the potential of emissions reduction in China: An implication from data envelopment analysis. Renew. Sustain. Energy Rev. 2017, 71, 859-872. [CrossRef]

50. The State Council. 2017. Available online: http:/ / www.scio.gov.cn (accessed on 11 March 2017).

51. Ministry of Environmental Protection. 2017. Available online: http://www.zhb.gov.cn/ (accessed on 12 March 2017).

52. Shan, H. Reestimating the capital stock in China: 1952-2006. J. Quant. Tech. Econ. 2008, 10, 17-31. (In Chinese) 
53. National Bureau of Statistics of China. China Statistical Yearbook 2005-2015; China Statistics Press: Beijing, China, 2005-2015. Available online: http://data.stats.gov.cn/easyquery.htm?cn=E0103 (accessed on 9 August 2016).

54. China Economic and Social Development Statistics Database. 2017. Available online: http://tongji.cnki.net/ kns55/index.aspx (accessed on 21 January 2017).

55. National Bureau of Statistics of China. China Labour Statistical Yearbook 2005-2015; China Statistics Press: Beijing, China, 2005-2015. Available online: http:/ / navi.cnki.net/KNavi/YearbookDetail?pcode=CYFD\& pykm=YZLDT\&bh=N2016030140 (accessed on 9 November 2016).

56. National Bureau of Statistics of China. China Energy Statistical Yearbook 2005-2015; China Statistics Press: Beijing, China, 2005-2015. Available online: http:/ / navi.cnki.net/KNavi/YearbookDetail?pcode=CYFD\& pykm=YCXME (accessed on 9 August 2016).

57. Du, L.M. Impact Factors of China's Carbon Dioxide Emissions: Provincial Panel Data Analysis. S. China J. Econ. 2010, 11, 20-33. (In Chinese)

58. National Coordination Committee on Climate Change, Energy Research Institute of National Development and Reform Commission. China's Greenhouse Gas Inventories; China Environment Science Press: Beijing, China, 2007. (In Chinese)

59. Intergovernmental Panel on Climate Change (IPCC). 2006 IPCC Guidelines for National Greenhouse Gas Inventories. Available online: www.ipcc.ch (accessed on 9 August 2016).

(C) 2017 by the authors. Licensee MDPI, Basel, Switzerland. This article is an open access article distributed under the terms and conditions of the Creative Commons Attribution (CC BY) license (http://creativecommons.org/licenses/by/4.0/). 